\title{
Hormonal treatment with Ovopel increases sperm production in lake minnow, Eupallasella percnurus (Pallas, 1814)
}

\author{
Rafał Kamiński, Sylwia Judycka, Justyna Sikorska, Jacek Wolnicki
}

Received - 18 May 2020/Accepted - 09 February 2021. Published online: 31 March 2021; @Inland Fisheries Institute in Olsztyn, Poland Citation: Kamiński, R., Judycka, S., Sikorska, J., Wolnicki, J. (2021). Hormonal treatment with Ovopel increases sperm production in lake minnow, Eupallasella percnurus (Pallas, 1814). Fisheries \& Aquatic Life 29(1), 50-53

\begin{abstract}
The aim of the study was to determine the suitability of Ovopel, which contains an mGnRH analog and metoclopramide (a dopamine inhibitor), for the stimulation of spermiation in the cyprinid fish lake minnow, Eupallasella percnurus (Pallas), which is endangered with extinction in Poland. The hormonal treatment effected an approximate twofold increase in sperm volume with a simultaneous decrease in sperm concentration and negligible differences in motility and straight-line velocity.
\end{abstract}

Keywords: CASA, hormonal stimulation, lake minnow, motility, quality, semen

\section{Introduction}

The lake minnow, Eupallasella percnurus (Pallas), is a cyprinid fish that is endangered with extinction in Poland (Wolnicki and Sikorska 2019). Since 2004, the active protection of this species has been mandated by law in Poland. This form of lake minnow

\footnotetext{
R. Kamiński [ झ], J. Sikorska, J. Wolnicki

Pond Fishery Department, Stanisław Sakowicz Inland Fisheries Institute, Piaseczno, Poland

E-mail: r.kaminski@infish.com.pl

S. Judycka

Department of Gametes and Embryo Biology, Institute of Animal Reproduction and Food Research, Polish Academy of Sciences,

Tuwima 10, 10-748 Olsztyn, Poland
}

protection includes captive breeding and the creation of banks of genetically profiled, cryopreserved semen (Kaczmarczyk and Wolnicki 2016). Artificial reproduction and sperm cryopreservation require volumes of semen large enough to collect without contamination and to fill cryopreservation straws, preferably without dilution. However, lake minnow males from Polish populations are not large (commonly 1-5 g BW), so they release very small amounts of semen. This practical difficulty could be overcome by applying a hormone treatment that increases semen volume (Król et al. 2009, Cejko et al. 2014, Mylonas et al. 2017). The standard procedure of the artificial propagation of the lake minnow includes using the hormonal preparation Ovopel to induce ovulation in females (Kamiński et al. 2004), but it has never been used to stimulate males. Therefore, the aim of this study was to determine the influence of Ovopel hormonal treatment on semen quantity and quality in this species.

\section{Material and Methods}

The lake minnow males originated from two Polish habitats: Mikołajki Pomorskie (5350'23'N $\left.19^{\circ} 10^{\prime} 42^{\prime \prime} \mathrm{E}\right)$ and Działy Czarnowskie (52 $28^{\circ} 48^{\prime \prime} \mathrm{N}$, $\left.21^{\circ} 14^{\prime} 52^{\prime \prime} \mathrm{E}\right)$. The fish were caught in baited traps in

\footnotetext{
(c) Copyright by Stanisław Sakowicz Inland Fisheries Institute in Olsztyn.

C 2020 Author(s). This is an open access article licensed under the Creative Commons Attribution-NonCommercial-NoDerivs License (http://creativecommons.org/licenses/by-nc-nd/3.0/).
} 
Table 1

Size and condition factor $(\mathrm{K})$ of lake minnow males from different populations stimulated or not stimulated with Ovopel

\begin{tabular}{|c|c|c|c|c|}
\hline \multirow[b]{2}{*}{ Parameters } & \multicolumn{2}{|c|}{ Działy Czarnowskie } & \multicolumn{2}{|c|}{ Mikołajki Pomorskie } \\
\hline & stimulated & non-stimulated & stimulated & non-stimulated \\
\hline Body weight (g) & $3.78 \pm 1.16^{\mathrm{a}}$ & $3.10 \pm 0.99^{\mathrm{a}}$ & $3.36 \pm 0.86^{\mathrm{a}}$ & $3.94 \pm 0.86^{\mathrm{a}}$ \\
\hline Total length (mm) & $74.7 \pm 8.2^{\mathrm{a}}$ & $68.6 \pm 6.1^{\mathrm{a}}$ & $69.1 \pm 5.3^{\mathrm{a}}$ & $73.3 \pm 5.2^{\mathrm{a}}$ \\
\hline $\mathrm{K}$ & $0.88 \pm 0.05^{\mathrm{b}}$ & $0.94 \pm 0.11^{\mathrm{ab}}$ & $1.00 \pm 0.05^{\mathrm{a}}$ & $0.98 \pm 0.03^{\mathrm{a}}$ \\
\hline
\end{tabular}

All data are expressed as means \pm SD (Tukey's test, $n=10$ ). Means followed by the same lower case letter are not significantly different at $\mathrm{P}<0.05$.

May at a water temperature of about $18^{\circ} \mathrm{C}$. The fish were acclimated in a $200 \mathrm{l}$ flow-through tank for two weeks under the following conditions: water temperature $15^{\circ} \mathrm{C}\left( \pm 0.5^{\circ} \mathrm{C}\right), \mathrm{pH} 7.8-8.1$, oxygen saturation $78-89 \%$, water exchange $11 \mathrm{~min}^{-1}$. The fish were not fed during the acclimation period. Only males releasing milt were selected for the experiment. Two experimental groups of 10 fish each were created for each population and kept separately. One group was stimulated with Ovopel according to the method described by Kamiński et al. (2004), while the second one was a control group not treated with any stimulator. Stimulation was applied with a single intraperitoneal injection of Ovopel, 2 pellets $\mathrm{kg}^{-1}$ (Kamiński et al. 2004). A single pellet weighed approximately $25 \mathrm{mg}$ and contained $18-20 \mu \mathrm{g}$ of D-Ala ${ }^{6}$, Pro ${ }^{9} \mathrm{NEt}-\mathrm{mGnRH}$ and $8-10 \mathrm{mg}$ of the dopamine antagonist metoclopramide (Horváth et al. 1997). After the hormonal injection, the tank water temperature was gradually increased over $6 \mathrm{~h}$ from $15^{\circ} \mathrm{C}$ to $17.0-18.5^{\circ} \mathrm{C}$ in both groups.

Sperm was collected from the fish $24 \mathrm{~h}$ after injection. Prior to the collection procedure, the males were sedated by immersion in an $80 \mathrm{mg} \mathrm{l}^{-1} \mathrm{MS}-222$ (tricaine methanesulfonate) solution (Argent Chemical Laboratories, USA). The sperm, obtained by gentle abdominal massage, was collected individually with special care to avoid contamination with blood or excrement.

Sperm motility characteristics were measured using a two-step procedure described by Wojtczak et al. (2007) and modified by Dietrich et al. (2014). Motility (MOT) and straight line velocity (VSL) were determined. All measurements of motility were made at least in duplicate for each sample for at least 50 spermatozoa per record. Sperm concentration was measured using spectrophotometry (Ciereszko and Dabrowski 1993).

Within a few days after the experiment, all the fish were released into the water bodies they originated from. All experimental procedures, including hormonal stimulation, were conducted according to the method described by Kamiński et al. (2004) and were approved by the Local Ethic Committee for Animal Experiments in Olsztyn (No. 15/2015).

Percentages were normalized via arc-sine transformation prior to statistical analysis. Values of fish size and condition (Table 1) were analyzed using one-way analysis of variance (ANOVA), followed by Tukey's test for post hoc comparison of means. Data concerning the effects of hormonal stimulation were analyzed using the $t$-test. All analyzes were performed using Statistica 8.0 software (StatSoft, Tulsa, OK, USA).

\section{Results}

The semen obtained from the fish treated with Ovopel was characterized by a higher volume, but the sperm concentration was lower in comparison to the control group $(\mathrm{P}<0.01$, Table 2$)$. Sperm motility was high in all experimental groups (84.2-93.0\%). In semen obtained from non-stimulated fish, sperm motility was similar to that in the stimulated fish $(\mathrm{P}>$ 0.01). The VSL values did not differ in the semen obtained from the non-stimulated or stimulated males. 
Table 2

Effects of hormonal stimulation with Ovopel on lake minnow sperm concentration, volume, motility, and straight line velocity

\begin{tabular}{|c|c|c|c|}
\hline \multirow[b]{2}{*}{ Semen characteristics } & Control & Ovopel-induced & \multirow[b]{2}{*}{$\mathrm{P}$} \\
\hline & $($ mean $\pm \mathrm{SD})$ & $($ mean $\pm \mathrm{SD})$ & \\
\hline \multicolumn{4}{|l|}{ Działy Czarnowskie population } \\
\hline Volume $(\mu \mathrm{l})$ & $14.5 \pm 7.2$ & $66.3 \pm 46.6$ & 0.0011 \\
\hline Concentration $\left(\mathrm{x} 10^{9} \mathrm{ml}^{-1}\right)$ & $8.91 \pm 2.90$ & $4.75 \pm 2.42$ & 0.0000 \\
\hline Motility (\%) & $93.0 \pm 6.4$ & $85.1 \pm 10.1$ & 0.0130 \\
\hline Straight line velocity $\left(\mu \mathrm{m} \mathrm{s}^{-1}\right)$ & $110.9 \pm 26.1$ & $98.1 \pm 31.5$ & 0.2431 \\
\hline \multicolumn{4}{|l|}{ Mikołajki Pomorskie population } \\
\hline Volume $(\mu \mathrm{l})$ & $60.4 \pm 13.8$ & $112.0 \pm 16.9$ & 0.0000 \\
\hline Concentration $\left(\mathrm{x} 10^{9} \mathrm{ml}^{-1}\right)$ & $13.66 \pm 1.76$ & $7.95 \pm 1.54$ & 0.0000 \\
\hline Motility (\%) & $89.7 \pm 10.7$ & $84.2 \pm 11.2$ & 0.0707 \\
\hline Straight line velocity $\left(\mu \mathrm{m} \mathrm{s}^{-1}\right)$ & $101.8 \pm 31.4$ & $124.2 \pm 33.5$ & 0.0527 \\
\hline
\end{tabular}

All data are means (Student's t-test, $\mathrm{n}=10$ )

\section{Discussion}

This study provides the first evidence of Ovopel stimulating spermiation in the lake minnow. This treatment caused increased semen hydration that manifested in an approximate twofold increase in volume and a simultaneous decrease in concentration. Hormonal stimulation with Ovopel had no considerable effect on sperm motility or VSL. All these effects of hormonal stimulation are known from studies of other fish species (Park et al. 2002, Król et al. 2009, Cejko et al. 2014, Mylonas et al. 2017).

The small body size is a characteristic feature of lake minnow males (Sikorska et al., unpublished), which is obviously an important limitation for the amount of sperm released. Our results indicated that collecting lake minnow sperm in amounts sufficient for artificial reproduction or effective cryopreservation could be very difficult without hormonal stimulation, especially with the smallest individuals weighing only 1-2 g BW. This difficulty could potentially lead to the undesirable effect of eliminating such individuals as sperm donors, and, further, to reduced genetic resources of lake minnow stocking material and in gene banks. Furthermore, the higher volume of semen obtained thanks to hormonal stimulation could considerably simplify sperm cryopreservation procedures, making it possible to use commercially available $250 \mu \mathrm{l}$ straws instead of the smaller, manually-cut $100 \mu \mathrm{l}$ straws used by Dietrich et al. (2015). Although the predilution of semen in an immobilizing solution could be used to increase its volume to facilitate cryopreservation, this procedure seems to significantly decrease post-thaw sperm motility (Judycka et al., unpublished).

In summary, Ovopel hormonal treatment proved to be beneficial for the amount of lake minnow semen without any considerable decrease in quality. Therefore, the procedure applied in the present study can be recommended for the artificial reproduction of this species and also for creating banks of cryopreserved semen.

Author contributions. R.K. performed field and laboratory work, contributed to data analysis, and wrote the paper; S.J. co-designed the study, performed laboratory work, contributed to data analysis, and participated in writing the paper; J.S. performed laboratory work and participated in writing the paper; J.W. conceived of and co-designed the study, led the field and laboratory work, and participated in writing the paper.

Acknowledgements. This study was financed by the Ministry of Science and Higher Education in Poland as part of Project No. N N304 324839 for 2010-2013 and by the National Science Centre in Poland under Project No. 2014/15/B/NZ9/05240 for 2015-2019.

We would like to thank G. J. Dietrich for his reliable assistance in laboratory work. 
ORCID iD

Rafał Kamiński https://orcid.org/0000-0002-8138-3327

Sylwia Judycka iD https://orcid.org/0000-0002-1410-3866

Justyna Sikorska iD http://orcid.org/0000-0001-8575-7034

Jacek Wolnicki iD https://orcid.org/0000-0003-4396-390X

\section{References}

Cejko, B.I., Żarski, D., Judycka, S., Kucharczyk, D., Sarosiek, B., Kowalski, R.K. (2014). Effect of two commercial preparations containing different $\mathrm{GnRH}$ analogues with dopamine antagonists on barbel Barbus barbus (L.) sperm quantity and quality. Aquaculture International, 22(1), 97-109.

Ciereszko, A., Dabrowski, K. (1993). Estimation of sperm concentration of rainbow trout, whitefish and yellow perch using a spectrophotometric technique. Aquaculture, 109(3-4), 367-373.

Dietrich, G.J., Pecio, A., Sikorska, J., Wolnicki, J., Słowińska, M., Hliwa, P., ... Ciereszko, A. (2014). Characterization of lake minnow Eupallasella percnurus semen in relation to sperm morphology, regulation of sperm motility and interpopulation diversity. Journal of Fish Biology, 85(2), 446-455.

Dietrich, G.J., Wolnicki, J., Słowińska, M., Sikorska, J., Hliwa, P., Kamiński, R., ... Ciereszko, A. (2015). Short-term storage and cryopreservation of lake minnow (Eupallasella percnurus (Pallas, 1814)) sperm. Journal of Applied Ichthyology, 31, 75-78.

Horvath, L., Szabo, T., Burke, J. (1997). Hatchery testing of $\mathrm{GnRH}$ analogue-containing pellets on ovulation in four cyprinid species. Polskie Archiwum Hydrobiologii, 44, 221-226.

Kaczmarczyk, D., Wolnicki, J. (2016). Genetic diversity of the critically endangered lake minnow Eupallasella percnurus in Poland and its implications for conservation. PloS one, 11(12), e0168191.

Kamiński, R., Kusznierz, J., Myszkowski, L., Wolnicki, J. (2004). The first attempt to artificially reproduce the endangered cyprinid lake minnow Eupallasella perenurus (Pallas). Aquaculture International, 12(1), 3-10.

Król, J., Kowalski, R.K., Hliwa, P., Dietrich, G.J., Stabiński, R., Ciereszko, A. (2009). The effects of commercial preparations containing two different GnRH analogues and dopamine antagonists on spermiation and sperm characteristics in the European smelt Osmerus eperlanus (L.). Aquaculture, 286(3-4), 328-331.

Mylonas, C.C., Duncan, N.J., Asturiano, J.F. (2017). Hormonal manipulations for the enhancement of sperm production in cultured fish and evaluation of sperm quality. Aquaculture, 472, 21-44.

Park, I.S., Choi, G.C., Kim, D.S., Nam, Y.K. (2002). The effect of exogenous hormone treatment on spermiation in Rhynchocypris oxycephalus (Sauvage and Dabry). Journal of the World Aquaculture Society, 33(4), 494-500.

Wojtczak, M., Dietrich, G.J., Irnazarow, I., Jurecka, P., Słowińska, M., \& Ciereszko, A. (2007). Polymorphism of transferrin of carp seminal plasma: relationship to blood transferrin and sperm motility characteristics. Comparative Biochemistry and Physiology Part B: Biochemistry and Molecular Biology, 148(4), 426-431.

Wolnicki, J., Sikorska, J. (2019), Prospects for the protection of the cyprinid fish endangered in Poland, lake minnow Eupallasella percnurus (Pall.), in the light of the results of its monitoring. Komunikaty Rybackie 6, 6-16 (in Polish). 